\title{
ANALYZING BIG TABLES AT SPREADSHEET EXCEL
}

\section{Agneša GAŠPERANOVÁ}

\begin{abstract}
The electronic spreadsheet is basic tool for business modeling, simulation and decision making. Important part of spreadsheet using is processing large tables, especially computing subtotals. This paper presents the course of creating subtotals, witch author used for teach-in Excel at academic year 2009/2010 at The Faculty of National Economy, University of Economics in Bratislava.
\end{abstract}

Key words: electronic spreadsheet, subtotals, pivot tables, database functions

\section{ANALÝZA ROZSIAHLYCH TABULIEK V EXCELI}

Resumé: Tabul'kový kalkulátor je základný pracovný nástroj dátovej analýzy, ktorý sa využiva pre ekonomické modelovanie, simuláciu, podporu rozhodovania. Významnou oblastou využivania tabul'kového kalkulátora je spracovanie vel'kých tabuliek, hlavne výpočet medzisúčtov. Článok opisuje kurz tvorby medzisúčtov, ktorý autorka využivala na cvičeniach Excel v akademickom roku 2009/2010 na Národohospodárskej fakulte Ekonomickej univerzity v Bratislave.

Kl'účové slová: tabul'kový kalkulátor, medzisúčty, kontingenčná tabul'ka, databázové funkcie

\section{1 Úvod}

Tabul'kový kalkulátor Excel je jedným z najdôležitejších aplikácií na riešenie úloh $\mathrm{v}$ oblasti administratívy a manažmentu. Študenti Národohospodárskej fakulty Ekonomickej univerzity $\mathrm{v}$ Bratislave absolvujú $\mathrm{v}$ druhom semestri štúdia cvičenie,, v ktorom by mali získat' zručnosti pokročilého alebo aspoň mierne pokročilého používatel'a tabul'kového kalkulátora Excel. Nestačí však, aby študenti zvládli použitie konkrétnych nástrojov, musia pochopit' ich význam a možnosti využitia. Skúsenosti pri testovaní ukázali, že úspešnost' študentov závisí nielen od ich vedomostí, ale ja od toho, ako je úloha sformulovaná. Výsledky sú lepšie, ak zadanie obsahuje určitý návod na riešenie. Študenti, ktorí ovládajú konkrétny pracovný nástroj, vyriešia zdanie bez väčších problémov. Dokazuje to vyhodnotenie dvoch testov na spracovanie rozsiahlych tabuliek, ktoré študenti absolvovali $\mathrm{v}$ letnom semestri akademického roku 2008/2009. Prvý test na zistenie medzisúčtov obsahuje $\mathrm{v}$ zadaní použitý prostriedok (kontingenčná tabul'ka $\mathrm{s}$ opisom štruktúry tabul'ky), v druhom teste návod chýba (analyzujte údaje, zistite súčet), úlohu môže študent riešit' l'ubovol'ným nástrojom, ale musí ho nájst' sám. Podmienkou úspešnosti bolo získanie viac ako $50 \%$ bodov. Testy riešilo 117 študentov, prvý test úspešne vyriešilo $78 \%$, druhý iba 48 \% študentov.
Výučba pokročilých nástrojov tabul'kového kalkulátora nastol'uje niekol'ko problémov. Prvý problém je hladanie vhodných príkladov na demonštráciu, druhý problém je nájdenie vhodného nástroja na riešenie problému, prípadne porovnanie nástrojov, ak sa úloha dá riešit' rôznymi prostriedkami, čo je typické hlavne pri spracovaní rozsiahlych tabuliek.

Klasický postup pri výučbe je vytvorenie vhodného príkladu pre každý nástroj osobitne, čo je jednoduchšie, lebo tabul'ka musí splnit' menej podmienok. V akademickom roku 2009/2010 sme zmenili prístup pri vyučovaní nástrojov na analýzu a spracovanie údajov, kládli sme väčší dôraz na význam použitých prostriedkov, snažili sme vysvetlit' princíp, nielen postup riešenia. Poukázali sme aj na možnost' získania výsledkov rôznymi postupmi, ak to bolo $\mathrm{v}$ úlohe možné, analyzovali sme alternatívne riešenia, porovnávali jednotlivé prostriedky.

Vytvorenie demonštračných tabuliek bolo náročnejšie, pretože sme ich spracovali rôznymi nástrojmi. Museli sme vytvorit' vel'ké tabul'ky s obsahom, ktorý je vhodný na demonštrácia rôznych nástrojov dátovej analýzy. Záverečné testovanie ukázalo, že výsledky študentov sa zlepšili, úlohu úspešne vyriešilo $60 \%$ študentov, aj ked' si študenti museli zvolit' postup sami, v zadaní chýbal návod na riešenie.

V článku uvádzame príklady, ktoré tvoria štvrtinu rozsahu semestrálnej látky cvičenia. 


\section{Kumulatívne výpočty- minikurz Excel}

Tabul'kový kalkulátor poskytuje účinné nástroje na spracovanie rozsiahlych tabuliek. Analýza údajov je dôležitou stránkou využivania informácií, uložených $\mathrm{v}$ tabul'kovej forme. Funkcie a databázové nástroje umožnia získat' prehl'adné informácie jednoducho a rýchlo. V článku uvedieme príklady na vyhl'adávanie informácií a efektívne vytváranie tzv. medzisúčtov v tabul'kách. Medzisúčty systémov na spracovanie hromadných údajov označujú prostriedky na získanie kumulatívnych údajov, okrem súčtov napríklad aj maximum, minimum, početnost' a priemer hodnôt $\mathrm{v}$ skupine údajov tabul'ky, pričom skupinu tvoria riadky so zhodnou hodnotou kl'účovej položky, stlpca.

\section{Využivané prostriedky}

Prostriedky a postupy, používané pri analýze údajov, uložených v tabul'ke, závisia od množiny skúmaných informácií a od požiadaviek, ktoré na výsledky kladieme. Ponuka prostriedkov v tabul'kovom procesore je bohatá, tie isté výsledky môžeme niekedy získat' rôznymi postupmi. V článku použijeme na riešenie úloh databázové nástroje (filter, medzisúčty, kontingenčné tabul'ky), ale aj databázové funkcie a vybrané štatistické a matematické funkcie. Pokúsime sa ukázat' rôzne postupy riešenia tej istej úlohy, porovnat' ich náročnost', výhody a nevýhody pre konkrétny príklad.

Úlohy riešime na demonštračnom príklade, využívame databázovú tabul'ku, ktorá obsahuje prehl'ad výkonov servisnej organizácie, ktorá zabezpečuje služby pre zákazníkov $\mathrm{v}$ desiatich krajinách Európskej únie. Faktúry vybraných služieb sledujeme $\mathrm{v}$ priebehu 12 mesiacov, od 1.5.2009 do 30.4.2010, tabul'ka obsahuje 696 riadkov. Našou úlohou bude spočítat výšku faktúr podl'a rôznych hl'adísk (krajina, predajca, dátum). Prvé riadky tabul'ky sú na obrázku 1.

\begin{tabular}{|l|l|r|r|r|}
\hline \multicolumn{2}{|c|}{ krajina } & meno & dátum kód služby & \multicolumn{1}{|c|}{ faktúra } \\
\hline DE & Decker & 3.5 .2009 BC 369521 & $485,00 €$ \\
\hline AT & Kanev & 4.5 .2009 HZ 258369 & $98,00 €$ \\
\hline HU & Karacs & 5.5 .2009 GY 147963 & $686,00 €$ \\
\hline
\end{tabular}

Obr. 1: Štruktúra tabulky

\section{Možnosti sčitovania údajov v tabul'ke}

$\mathrm{V}$ texte uvedieme niekol'ko príkladov sčitovania údajov. Počet, priemer, maximum, minimum získame podobne, väčšinou stačí zvolit' pri definovaní zadania vhodnú funkciu, respektíve upravit' argumenty funkcie. Položka, ktorá určí skupinu, je klúč výberu riadkov na tvorbu medzisúčtu. Výsledkom bude súčet hodnôt vybraného stĺpca tabul'ky z tých riadkov, ktoré majú rovnakú klúčovú položku. Príklady riešime v Excel 2007.

Označenie rozsiahlej tabul'ky je niekedy problematické. Ked' tabul'ku označíme pred začatím operácie, pomôžeme si klávesovými skratkami, presunieme kurzor do tabul'ky a stlačíme kombináciu klávesov $\mathrm{Ctrl}+\mathrm{A}$, alebo Ctrl+*. Databázové nástroje nevyžadujú označenie tabul'ky, stačí pred výberom príkazu presunút' kurzor do tabul'ky, Excel po zadaní príkazu rozšíri označenie na celú tabul'ku. Ťažkosti môžu nastat', ak databáza je argument funkcie, vtedy tieto pomôcky nefungujú. Riešenie je použitie názvov, ktoré spravujeme skupinou nástrojov definované názvy v príkaze vzorce. Po označení tabul'ky príkaz definovat' názov pomenuje celú tabul'ku, príkaz vytvorit' názov $z$ výberu pomenuje stĺpce a/alebo riadky tabul'ky. $\mathrm{V}$ našom príklade databáza_faktúr je názov tabulky, menovky stĺpcov označujú stĺpce tabul'ky (hodnoty stípca bez menovky). Výhodou názvov je fakt, že sú to absolútne odkazy, sú jednoznačným označením oblasti, platné $\mathrm{v}$ hárku alebo v celom zošite, čo je náš prípad.

Súčet údajov podl'a jednej kl'účovej položky získame rôznymi spôsobmi, uvedieme najčastejšie používané.

\section{Medzisúčty}

Súčet faktúr podl'a jednotlivých krajín l'ahko získame databázovým nástrojom medzisúčty príkazu údaje, postup má ale jedno úskalie, výsledky sú správne iba vtedy, ak je tabul'ka usporiadaná podl'a klúčovej položky, v našom prípade to je krajina.

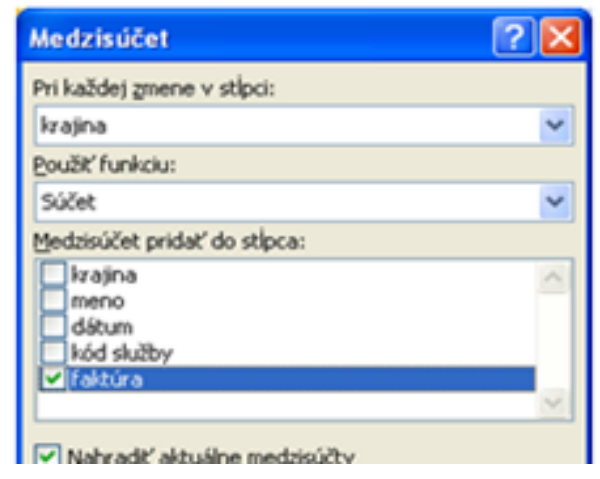

Obr. 2: dialógové okno medzisúčty

Skupiny tvorí položka krajina, pri každej zmene hodnoty v stĺpci krajina sa do tabul'ky doplní medzisúčet. Zvolili sme funkciu súčet, medzisúčet pridáme do stĺpca faktúra ( pre každú 
krajinu sa spočítajú hodnoty faktúr), označenie medzisúčtu sa vloží do stĺpca krajina, súčet faktúr do stĺpca faktúra (pozri obrázok 3). Výpočet realizuje Excel použitím matematickej funkcie Subtotal(function_num,ref). Prvý argument je číslo funkcie (priemer je 1, počet 2, súčet 9), druhý argument je odkaz na súvislú oblast' riadkov s rovnakou kl'účovou hodnotou. Funkciu môžeme vložit' do tabul'ky aj priamo, ale nástroj medzisúčty je efektívnejší. V prípade potreby môžeme doplnit' počet faktúr, ked' opakujeme postup tvorby medzisúčtov, použijeme funkciu Počet a $v$ dialógovom okne zrušíme označenie nahradit' medzisúčty.

\begin{tabular}{|c|c|c|c|c|c|c|}
\hline \begin{tabular}{l|l|l|l|}
1 & 2 & 3
\end{tabular} & 4 & A & B & C & D & E \\
\hline \multirow{2}{*}{+} & 1 & krajina & \multicolumn{4}{|c|}{ meno dátum kód služby faktúra } \\
\hline & 74 & AT Celkom & & & & $51840,00 €$ \\
\hline+ & 111 & CZ Celkom & & & & $20553,00 €$ \\
\hline+ & 196 & DE Celkom & & & & $58329,00 €$ \\
\hline+ & 233 & FR Celkom & & & & $26083,00 €$ \\
\hline+ & 320 & GB Celkom & & & & $64649,00 €$ \\
\hline+ & 477 & HU Celkom & & & & $110365,00 €$ \\
\hline+ & 514 & IT Celkom & & & & $23696,00 €$ \\
\hline+ & 611 & SK Celkom & & & & $65217,00 €$ \\
\hline+ & 696 & SR Celkom & & & & $59304,00 €$ \\
\hline+ & 707 & sw Celkom & & & & $7848,00 €$ \\
\hline - & 708 & Celkový súče & & & & $487884,00 €$ \\
\hline
\end{tabular}

\section{Obr. 3 Súčet faktúr jednotlivých krajín}

\section{Funkcia Sumif}

Funkcia Sumif sčituje údaje definovaného stípca riadku, $\mathrm{v}$ ktorom hodnota klúčovej položky vyhovuje podmienke. Výhodou funkcie je, že tabul'ka nemusí byt' usporiadaná, nevýhodou naopak je fakt, že pre každú hodnotu klúčovej položky musíme zostrojit' funkciu. Vhodným umiestnením vzorcov a úpravou odkazov však môžeme vytvorit' kopírovatel'né vzorce a tým zjednodušit' postup. $\mathrm{V}$ našom príklade sme ako argumenty funkcie použili názvy stĺpcov, =Sumif(krajina;K2;faktúra) je vzorec v bunke $K 3$, kde krajina je názov prvého stĺpca tabul'ky, faktúra je názov stípca s hodnotou faktúr. Názov je absolútny odkaz, vzorec môžeme skopírovat' do ostatných buniek riadku.

\begin{tabular}{|c|c|c|c|c|c|c|c|c|c|c|c|}
\hline 4 & J & K & L & M & $\mathrm{N}$ & 0 & $\mathrm{P}$ & Q & $\mathrm{R}$ & $\mathrm{s}$ & $\mathrm{T}$ \\
\hline \multicolumn{12}{|l|}{1} \\
\hline 2 & krajina & HU & SR & $\mathrm{CZ}$ & AT & DE & $F R$ & GB & IT & SK & SW \\
\hline 3 & faktúry & 110365 & 59304 & 20553 & 51840 & 58329 & 26083 & 64649 & 23696 & 65217 & 7848 \\
\hline
\end{tabular}

\section{Obr. 4: Súčet faktúr, vypočitaný funkciou Sumif}

Funkcia =Countif(krajina; $K 2)$ vypočíta počet, $=$ Averageif(krajina; $K 2 ;$ faktúra) priemernú hodnotu faktúr krajiny. Spomenuté funkcie nenahradia medzisúčty, nakol'ko neexistujú podmienené funkcie všetkých medzisúčtov, riešením môžu byt' databázové funkcie.

\section{Funkcia Dsum}

Vybrané matematické a štatistické funkcie, majú svoju obdobu databázových funkcií. Výhodou týchto funkcií je ich jednoduchost', každá databázová funkcia má rovnakú štruktúru: Dfunkcia(database,field,criteria). Databázová funkcia spracuje celú databázu (prvý argument je odkaz na oblast', alebo názov tabul'ky), hl'adá riadky tabul'ky, ktoré spíňajú kritériá (tretí argument funkcie) a spracuje hodnoty vo zvolenom stípci (druhý argument), v príklade je to číslo stĺpca, ale môžeme použit' názov v tvare ret’azca („faktúra“) alebo adresu bunky, v ktorej je nadpis stĺpca. V príklade hodnotu faktúr spočíta funkcia Dsum.

Nevýhodou databázových funkcií môže byt', že pre každú hodnotu klúčcového stĺpca musíme vytvorit' vlastnú oblast' kritérií. V príklade sú jednoduché kritériá, výber určuje iba jedna hodnota, tak sme výberové podmienky vytvorili skopírovaním do súvislej oblasti nad oblast'ou, kam sme vkladali funkciu. V prvom argumente je názov tabul'ky, do bunky $K 12$ sme uložili vzorec =DSUM(databáza_faktúr;5;K8:K9), potom sme ho skopírovali do ostatných buniek.

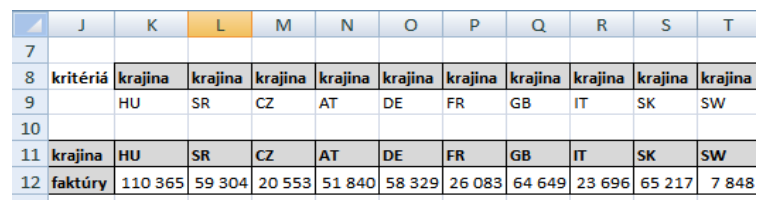

Obr. 5: Súčet faktúr, vypočitaný funkciou Dsum

Kritérium môže byt' l'ubovol'ne zložité, čo na jednej strane rozširuje množinu riešitel'ných príkladov, na druhej strane zvyšuje prácnost' a tým časovú náročnost' vytvárania vzorcov.

\section{Kontingenčná tabul'ka}

Efektívnym nástrojom získania medzisúčtov je kontingenčná tabul'ka. Vytvorenie a úprava kontingenčnej tabul'ky je otázkou niekol'kých minút. Kurzor presunieme do databázovej tabul'ky, potom v príkaze Vložit' kontingenčnú tabul'ku definujeme umiestnenie tabul'ky, čím otvoríme okno Polia kontingenčnej tabulky. Kritickým bodom návrhu je umiestnenie položiek databázy do vhodnej oblasti polí. Kl'účové položky budú polia riadkov alebo stípcov (v našom príklade je jediná stípcová položka, krajina), údajové položky tvoria spracované hodnoty (v príklade pole faktúra). Implicitné nastavenie funkcie spracovania pre číselné hodnoty je súčet, pre ostatné hodnoty počet. Ked' kurzor je v oblasti údajov kontingenčnej tabul'ky, môžeme upravit' vlastnosti spracovaných údajov 
prípadne zmenit' funkciu spracovania. Príkaz nastavenie pol'a je $\mathrm{v}$ kontextovej ponuke ale aj v zozname príkazov názvu položky v časti definovania oblastí okna polia kontingenčnej tabul'ky Množinu zobrazených údajov môžeme upravit', ak do oblasti filter zostavy presunieme kl'účovú položku, podl'a možnosti položku, ktorá nemá príliš vel'a hodnôt a určíme filter zostavy, čím najčastejšie upravujeme podmienky na vytvorenie zostavy pre tlač. Podobne môžeme upravit' podmienky výberu pre riadkové a stĺpcové položky. Výhodou kontingenčnej tabul'ky je jednoduchá modifikácia tabul'ky, premiestnenie alebo rozšírenie spracovaných polí dáva úplne iný pohl'ad na pôvodnú tabul'ku. Tabul'ka na obrázku 6 je podobná riešeniu pomocou funkcií. Výsledok sa bude podobat' medzisúčtom, ak pole krajina presunieme do oblasti riadkov. Počet faktúr $\mathrm{v}$ medzisúčtoch zobrazíme pridaním d’alšej úrovne medzisúčtov, v kontingenčnej tabul'ke jednoducho vložíme do oblasti hodnôt l'ubovol'né d'alšie pole a v prípade potreby zmeníme funkciu na počet. V našom príklade je najvhodnejšie pole krajina, vtedy systém zvolí funkciu počet.

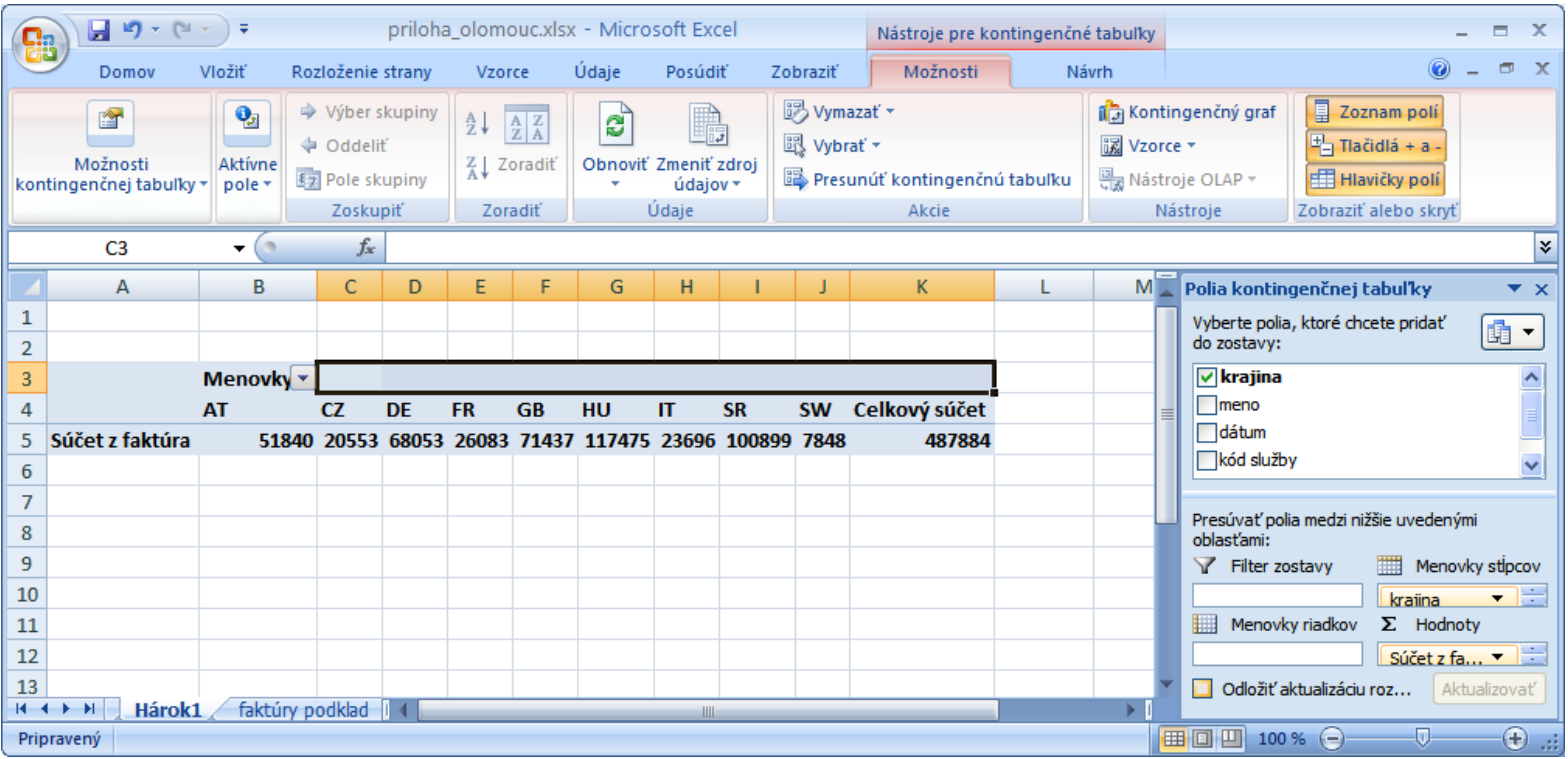

Obr. 6: Súčet faktúr, vypočitaný kontingenčnou tabul'kou

Pridaním d’alšieho pol'a do riadkových položiek vytvoríme dvojrozmernú tabul'ku, ktorú funkcie ani medzisúčty neumožnia vytvorit’.

Tabul'ka v našom príklade obsahuje dátum vystavenia faktúr. Tento údaj $\mathrm{v}$ prehl'adných výstupoch je príliš podrobný, potrebujeme väčšinou mesačné, prípadne štvrt'ročné a ročné výsledky. Medzisúčty a Sumif neumožnia vytvorit' takýto prehl'ad bez pomocných výpočtov $\mathrm{v}$ tabul'ke. Pomocou databázových funkcií by sme mohli úlohu vyriešit' tak, že definujeme výberové kritériá pre každý štvrt'rok, potom vytvoríme vzorce (funkcia Dsum), ročné výsledky získame sčítaním štvrt'ročných výsledkov alebo priamo, ak ako výberové kritérium použijeme rok.
Rozčlenenie časových medzisúčtov podl'a krajín je ešte zložitejšie. Pridanie d’alšej úrovne medzisúčtov databázy $\mathrm{v}$ upravenej tabul'ke je pomerne jednoduché, ak je tabul'ka vhodne usporiadaná, ale výsledok je hierarchicky členený, čo niekedy nestačí.

Kontingenčná tabul'ka umožní zoskupenie údajov. Do riadkových položiek tabul'ky vložíme dátum, kurzor presunieme na l'ubovolný dátum $\mathrm{v}$ kontingenčnej tabul'ke, $\mathrm{v}$ paneli nástrojov možností kontingenčnej tabul'ky alebo príkazom Zoskupit'v kontextovej ponuke otvoríme okno na tvorbu skupiny (štvrt'rok, rok). Výsledok bude dvojrozmerná tabul'ka, v ktorej sa zobrazia medzisúčty $v$ jednotlivých rokoch a štvrt'rokoch (pozri obrázok 7). 


\begin{tabular}{|c|c|c|c|c|c|c|c|c|c|c|c|}
\hline Súčet z faktúra & $\mathrm{Me}=$ & & & & & & & & & & \\
\hline Menovky riadkov & AT & $\mathrm{CZ}$ & DE & FR & GB & HU & IT & SK & SR & sw & Celkový súčet \\
\hline$\because 2009$ & 9372 & 5216 & 16320 & 7240 & 14298 & 26339 & 9672 & 20836 & 11402 & 2021 & 122716 \\
\hline štv2 & 98 & 3312 & 4671 & 3144 & 5582 & 13402 & 7573 & 9925 & 5386 & 231 & 53324 \\
\hline štv3 & 8359 & 1739 & 5676 & 2700 & 4208 & 8572 & 1374 & 6189 & 5657 & 1034 & 45508 \\
\hline štv4 & 915 & 165 & 5973 & 1396 & 4508 & 4365 & 725 & 4722 & 359 & 756 & 23884 \\
\hline$\boxminus \mathbf{2 0 1 0}$ & 42468 & 15337 & 42009 & 18843 & 50351 & 84026 & 14024 & 44381 & 47902 & 5827 & 365168 \\
\hline štv1 & 25872 & 11152 & 23950 & 12652 & 30827 & 55319 & 10537 & 26031 & 32458 & 3188 & 231986 \\
\hline štv2 & 16596 & 4185 & 18059 & 6191 & 19524 & 28707 & 3487 & 18350 & 15444 & 2639 & 133182 \\
\hline Celkový súčet & 51840 & 20553 & 58329 & 26083 & 64649 & 110365 & 23696 & 65217 & 59304 & 7848 & 487884 \\
\hline
\end{tabular}

Obr. 7: Súčet faktúr krajín, zoskupené podl'a rokov a štvrtrokov.

Pomocou databázovej funkcie síce vytvoríme tabul'ku, ale počet kritérií rastie, bude to počet štvrt'rokov krát počet krajín, a funkcie pravdepodobne nebudú kopírovatel'né. Túto istá úlohu vyriešime $\mathrm{v}$ kontingenčnej tabul'ke za minútu. Stačí vložit' položku krajina do oblasti menovky stĺpcov, dvojrozmerná kontingenčná tabul'ka obsahuje súčet faktúr, zoskupené podl'a rokov a $\mathrm{v}$ tom podla štvrt'rokov, rozčlenené podl'a krajín. Medzisúčty rokov a celkové súčty stípcov a riadkov môžeme podla potreby schovat' alebo zobrazit'.

Kontingenčné tabul'ky sú ako z príkladov vidiet' efektívne a l'ahko použitel'né, ale majú svoje nedostatky. Jednoduché úlohy je často lepšie riešit' pomocou funkcií, hlavne vtedy, ak výsledky chceme použit' ako operandy alebo argumenty d’alších výpočtov. Nevýhodu kontingenčnej tabul'ky je aj to, že pri vytvorení kontingenčnej tabul'ky systém pripraví podklady pre tvorbu tabul'ky, tieto pracovné výpočty sú náročné na pamät'. Vel'kost' pracovného zošita sa zväčší približne o tretinu, aj ked' výhodou je, že kontingenčné tabul'ky, vytvorené $\mathrm{z}$ tej istej tabul'ky majú spoločný pracovný priestor. Ďalšie kontingenčné tabul'ky sa vytvárajú na základe existujúceho pracovného priestoru, čo šetrí priestor a čas, tento fakt je ale aj nevýhodou, pretože zmeny $\mathrm{v}$ tabul'ke sa $\mathrm{v}$ kontingenčnej tabul'ke neprejavia automaticky, dokonca ani $\mathrm{v}$ tej, ktorú zostrojíme po úprave tabul'ky, kým funkcie a medzisúčty na úpravu tabul'ky reagujú okamžite. Kontingenčné tabul'ky musíme aktualizovat' príkazom obnovit' v kontextovej ponuke kontingenčnej tabul'ky, pričom ale stačí aktualizovat' jednu kontingenčnú tabul'ku, bez ohl'adu na tom, kol'ko sme ich vytvorili.

\section{Záver}

Spracovanie a analýza rozsiahlych tabuliek je náročnou úlohou. Excel poskytuje rôzne prostriedky na ich spracovanie, efektívnost' spracovanie a výsledok závisí od toho, či použijeme vhodný nástroj. Riešenie konkrétnej úlohy je často možné rôznymi prostriedkami, čo je na jednej strane užitočné, používatel' si môže vybrat' postup, ktorý mu vyhovuje, na druhej strane bohatá ponuka prostriedkov vyžaduje väčšie úsilie a viac času na ich zvládnutie.

V článku sme uviedli typické príklady na využívanie tabul'kového procesora na spracovania informácií a získanie podkladov na vyhodnotenie údajov a ekonomické modelovanie. Potrebné informácie môžeme získat' často rôznymi prostriedkami, záleží na konkrétnej situácii, ktorú alternatívu si zvolíme. Prostriedky tabul'kového procesora Excel sú bohaté a každou verziou sa rozširujú, je skoro nemožné všetky zvládnut', to ani nebolo účelom tohto článku. Chceli sme sa iba podelit's čitatel'mi o skúsenosti $\mathrm{s}$ využívaním menej známych ale $\mathrm{o}$ to užitočnejších prostriedkov Excelu a ukázat' príklady, ktoré by im mohli byt' užitočné pri riešení vlastných problémov.

\section{Literatúra:}

[1] BROŽ, M.: Microsoft Excel pro manažery a ekonomy. 5. Vyd. Praha : Computer Press, 2006. ISBN 8025113078

[2] CSAPÓ, B.: Formális és nem-formális tanulás során szerzett tudás integrálása (Integrácia vedomostí, získaných formálnym a neformálnym štúdiom). In: Iskolakultúra, roč. 2006, 2006, č. 2. ISNN 1215-5233

[3] DOUCEK, P, - NOVOTNÝ, O. PECÁKOVÁ, I. - VOŘÍŠEK, J.: Lidské zdroje v ICT - Analýza nabídky a poptávky po IT odbornících v ČR. 1. Vyd. Praha : Professional publishing, 2007. ISBN 978-80-86946-51-1.

[4] HUBA, M. - PIŠÚTOVA, GERBER, K.: Základy e-vzdelávania. Bratislava : STU, 2007. ISBN 978-80-89316-00-7. 
[5] HUNTER, M.: Účinné vyučování v kostce. Praha : Portál, 1999.

[6] KOMPOLTOVÁ, S. Pedagogika. Bratislava : Vydavatel'stvo Ekonóm, 2009. ISBN 978-80225-2805-4.

[7] RALSTON, A. - REILLY jr., $\quad$ E.: Encyclopedia of Computer Science and Engineering. New York : Van Mostrand Reinhold Company Inc., 1983.

[8] GAŠPERANOVÁ, A., LEDVÉNYI, S., ŠČESNÝ, R., ŠÓŠ, I.: Informatika praktikum. Bratislava : Vydavatel'stvo Ekonóm 2006. ISBN 80-225-2236-8.

RNDr. Agneša Gašperanová

Katedra aplikovanej informatiky a výpočtovej techniky

Národohospodárska fakulta

Ekonomická univerzita v Bratislave

Dolnozemská 1

85235 Bratislava

Slovensko

tel +421-02/6729 1274

E-mail: agnesa.gasperanova@euba.sk www pracoviska: www.euba.sk 